\title{
Validating and modelling technological pedagogical content knowledge framework among Asian preservice teachers
}

Ching Shing Chai,

National Institute of Education, Nanyang Technological University, Singapore

Eugenia M. W. Ng

The Hong Kong Institute of Education, Hong Kong SAR

Wenhao Li

Central China Normal University, Wuhan, China.

Huang-Yao Hong

National Chengchi University, Taiwan

Joyce H. L. Koh

National Institute of Education, Nanyang Technological University, Singapore

\begin{abstract}
The Technological Pedagogical Content Knowledge (TPCK) framework has been adopted by many educational technologists and teacher educators for the research and development of knowledge about the pedagogical uses of Information and Communication Technologies (ICT) in classrooms. While the framework is potentially very important, efforts to survey teachers' TPCK efficacy has yet to identify all seven factors postulated by the framework. This study attempted to validate a TPCK efficacy survey by implementing it on an Asian group of 550 preservice teachers from China, Hong Kong, Singapore and Taiwan. The seven factors underlying the TPCK framework were identified which suggested the research instrument to be valid and reliable. The structural equation model proposed based on the TPCK framework supported eight out of 12 hypotheses about the relationships between TPCK constructs. The results indicate that the positive effects of the basic knowledge factors of CK, PK, and TK were indirect, occurring through the second layer of knowledge factors (TPK, TCK, and PCK). Implications for preservice teacher professional developments are discussed.
\end{abstract}

\section{Introduction}

Information and Communication Technologies (ICT) have been viewed by many educators as an enabling factor for constructivist-oriented teaching and learning (Collins \& Halverson, 2010; Howland, Jonassen, \& Marra, 2012). These educators highlighted many affordances of ICT that would enable learners to construct deeper understanding about the subject matter they are learning through active and collaborative learning that is anchored around real-world authentic problems. Howland et al. (2012) characterized such learning as meaningful learning with ICT. However, the actualization of the pedagogical affordances are very much dependent upon teachers' beliefs and attitudes towards technology (Ertmer, 2005), the knowledge they possess (Mishra \& Koehler, 2006), and their capacity to design technology-integrated lessons (Chai, Koh \& Tsai, 2011a). In short, integrating technology into classroom teaching and learning is highly demanding on teachers' beliefs, knowledge and adaptive expertise (Darling-Hammond, Bransford, LePage, Hammerness, \& Duffy, 2005; Hong \& Sullivan, 2009; Kramarski \& Michalsky, 2010; Mishra, Koehler, \& Kereluik, 2009). This could perhaps explain the slow progress in the schools and teachers' pervasive use of ICT for students' constructivist-oriented learning (Harris, Mishra, \& Koehler, 2009). Mishra and Koehler (2006) and Graham (2011) have also pointed out that the lack of a theoretical framework is partly responsible for the lack of progress in school-based ICT integration. Drawing upon Shulman's (1986) idea of pedagogical content knowledge (PCK), Mishra and Koehler (2006), together with several other researchers (Niess, 2005; Angeli \& Valanides, 2005), put forth the theoretical framework of technological pedagogical content knowledge (TPCK). Since then, the TPCK framework has served as a guide to unpack ICT-integrated lessons; to develop ICT competencies among teachers in teacher education; to design classroom use of ICT and to frame literature review pertaining to ICT or educational technology (Polly, Mims, Shepherd, \& Inan, 2010). TPCK has been described as situated, complex, multifaceted, integrative and/or transformative in the knowledge domain (Angeli \& Valanides, 
2009; Harris et al., 2009; Koehler \& Mishra, 2009; Manfra \& Hammond, 2008). In essence, the TPCK framework built on the PCK framework, by synthesizing pedagogical knowledge (PK), content knowledge (CK), and technological knowledge (TK). The inclusion of TK is based on the need to account for the emerging role that technology plays in today classroom. The TPCK framework is usually depicted as Figure 1 below.

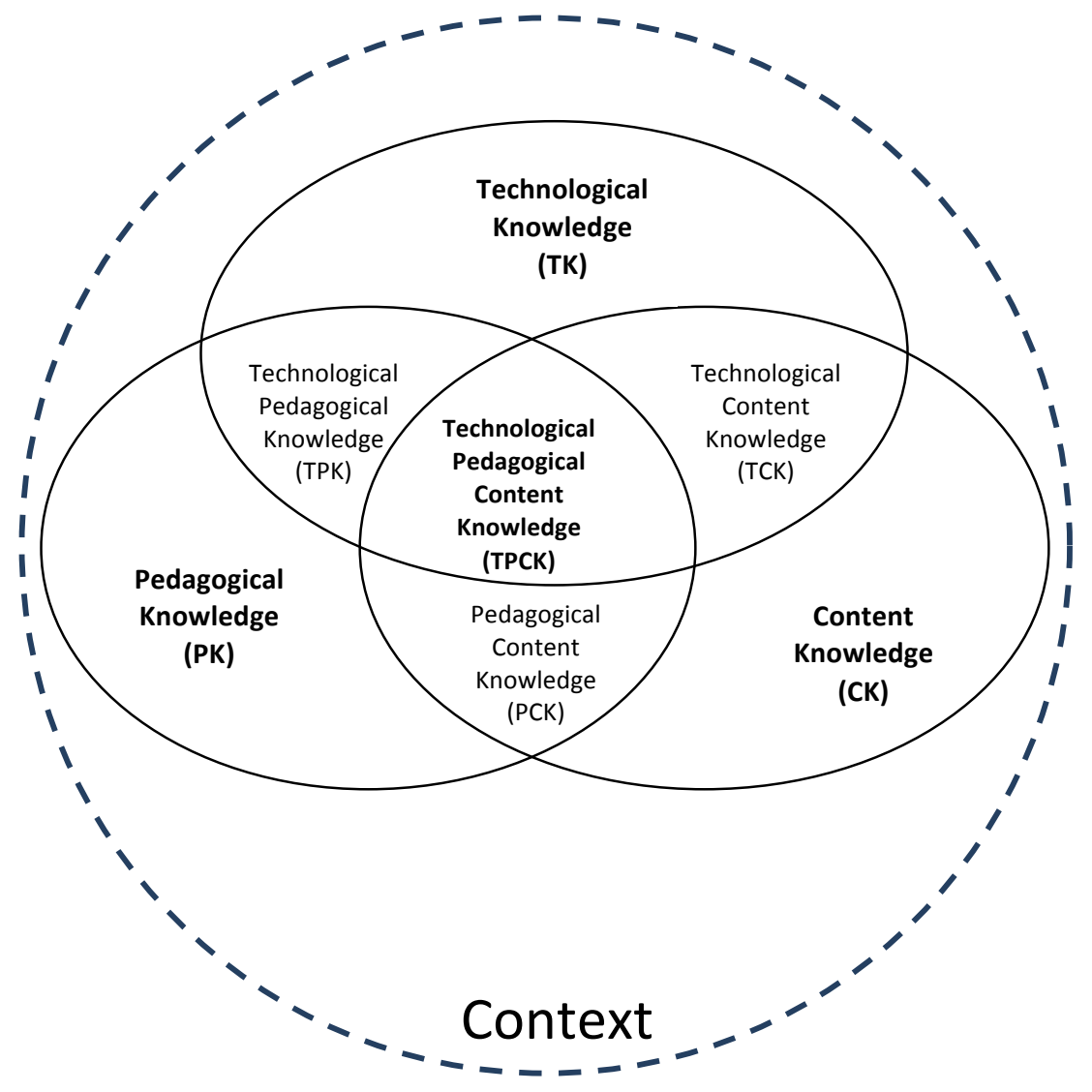

Figure 1. Technological pedagogical content knowledge framework (Koehler \& Mishra, 2009; p.63).

As reflected in the diagram, the three basic forms of knowledge interact to give rise to four derived forms of knowledge. These are pedagogical content knowledge (PCK), technological content knowledge (TCK), technological pedagogical knowledge (TPK), and technological pedagogical content knowledge (TPCK). PCK refers to the unique form of professional knowledge that teachers possess in making the content knowledge accessible to the students through some pedagogical methods. For example, guiding students through peer evaluation can be a means to build students' knowledge about what constitutes a good essay for language learning. TCK are technological representations of content knowledge and/or content specific software or hardware. For example, using Google Earth to find the route for attending a friend's birthday constitutes an application of TCK. Other examples of TCK include using qualitative research software such as Nvivo for social science research or the use of data logger for the collection of scientific data. TCK differs from TK in that it is content-specific whereas open software such as Microsoft Word and/or PowerPoint are content free software. In addition, TCK by itself is not related to teaching. On the other hand, TPK refers to knowledge about pedagogical uses of associated technology without considering the content knowledge. For example, to facilitate online discussion, teachers should use openended questions regardless of the subject matter. Howland et al.'s (2012) elaboration of the use of ICT as cognitive tools for many different forms of ICT (e.g., concept-mapping, online conferencing, communication tools etc.) provide extended TPK that teachers can draw upon when they are interested in using certain technological tools. Finally, TPCK is the synthesis of the six types of knowledge mentioned above but for a specific topic to be taught. 
Knowledge in the overlapping areas, i.e., TCK, TPK, TCK and TPCK are synthesized from multiple sources. Concerns about the confusion among these constructs have been highlighted by researchers such as Cox and Graham (2009). Without clear delineation of the constructs, confusion may arise when further research and development work are carried out based on the framework. For example, Polly et al. (2010) considered "using technology to address specific academic standards" and the design of "technology-rich units" (p. 866) as work in the area of TCK. As both statements involved pedagogical decisions, these may also be interpreted as TPCK . Such kinds of disputes may cause confusion among teachers when it is used in the context of teacher education. Cox and Graham (2009) emphasized the notion of independence when classifying the forms of knowledge. They urged researchers to be careful about making the boundary of each construct clear. This is especially important when surveying teachers as it is likely for teachers to consider these different forms of knowledge with the intent of using them for teaching. With such an awareness, we proceed to review issues related to the design of TPCK research instruments.

\section{Background of the Research Instrument}

Since 2005, the TPCK framework has been widely employed in the research and development of educational uses of technology (AACTE, 2008; Graham, 2011). The most common application of the framework is for the design and evaluation of teacher professional development courses. The key activity of these professional development courses revolve around engaging teachers in the design of ICTintegrated lessons. Most studies in this area, regardless of the research design employed, produced beneficial outcomes in enhancing teachers' performance or efficacy in integrating ICT (see Angeli \& Valanides, 2005, 2009; Chai et al., 2011a; Koehler \& Mishra, 2005; Koehler, Mishra \& Yahya, 2007; Tee \& Lee, 2011). Mishra and Koehler (2006) labelled the approach as learning by design. In addition, Koehler and Mishra, (2009) argued that the essence of TPCK lies in the educators' creativity and flexibility in creating lessons and experimenting with ICT to meet students' situated learning needs. As such, design is an authentic task for teachers as the ability to use ICT in a meaningful way involves teachers' ability to draw from relevant aspects of TPCK and synthesizing them for a particular group of students with a specific focus on some content knowledge. While the other six types of knowledge may be more or less codified, such as the TPK reported by Howland et al. (2012), TPCK remains to be highly volatile as teachers had to attend to the socio-historical development of the lessons and to contextualize the integration of ICT to extend students' understanding. In other words, teachers who wish to use ICT meaningfully needs to synthesize relevant knowledge drawn from the other six aspects of TPCK and to operationalize the knowledge resources drawn into lesson plans for implementation. This involves building teachers' design capacities to address emerging understanding among students. We see such endeavours as leveraging mainly on design thinking and the act of contextualizing TPCK is a form of knowledge creation pertinent to the teaching profession. Kramarski and Michalsky (2010) recognize that design tasks are cognitively demanding, especially for preservice teachers. They have created metacognitive prompts to support the preservice teachers when they are engaged in designing ICT integrated lessons. These studies point to the importance of facilitating and supporting teachers in designing technology-enhanced learning.

The emergence of the TPCK framework and researchers' interest in it leads to the development of instruments to measure teachers' self-efficacy of their TPCK knowledge (Graham, Burgoyne, Cantrell, Smith, St. Clair, \& Harris, 2009). However, existing questionnaires for teachers' self-assessment of their TPCK competencies are generally unable to identified the seven factors as postulated by the framework due to the overlapping nature of the framework (Cox \& Graham, 2009; Krauskopf, Zahn, \& Hesse, 2012; Voogt, Fisser, Pareja Roblin, Tondeur, \& van Braak, in press). Schmidt et al. (2009) surveyed 124 American preservice teachers about the seven factors of TPCK and claimed their instrument to be reliable and valid. However, as the factor analysis was conducted one factor at a time, the rigor of the factor analysis is questionable (see Voogt et al., in press). Sahin (2011) used similar processes and claimed to have validated a Turkish version of the TPCK survey. The practice of analysing the factors one by one is again methodologically dubious. Subsequently, Koh, Chai, and Tsai, (2010) used Schmidt et al.'s questionnaire with some adaptions to measure Singaporean preservice teachers $(\mathrm{N}=1185)$ perception of TPCK and identified five factors. While two distinct factors (CK, TK) were isolated, other technology related factors load as one (i.e., TPK, TCK, and TPCK) and the non technology-related PK and PCK loaded as another factor. The last factor was formed by two items related to teacher reflection about technology use and it was labelled as knowledge from critical reflection. Similar merging of factors was 
also reported by Archamabault and Barnett (2010) and Lee and Tsai (2010) when they attempted to create a survey for teachers targeted at the design of web-based learning. Based on their detailed conceptual analysis of the TPCK framework, Cox and Graham (2009) have demarcated the distinguishing features of these factors. Chai, Koh and Tsai (2011 b) built upon Cox and Graham (2009) conceptual analysis to refine their earlier survey (Koh, Chai, \& Tsai, 2010) and they were able to identify all seven factors, with an additional factor of a second CK through both exploratory and confirmatory factor analysis. The second CK corresponded to the second teaching subject that all Singaporean teachers are trained to teach. Chai et al. (2011b) pointed out the need to refine the survey as the sample size was relatively small $(\mathrm{N}=219)$, involving only teachers from Singapore. In addition, some factors had only 3 items (3 for CK1 and 3 for CK2; TPK) with both TCK and PCK for the first and second teaching subject loaded as one factor. In theory, if the CK factors split into two distinct factors, all content-related factors should also split into distinct factors. In other words, there should be two factors of TCK and PCK, corresponding to the first and second teaching subjects respectively.

\section{The Research Study}

The limitations of Chai et al.'s (2011b) study mentioned above leads us to select a similar and yet culturally more diverse group of Asian preservice teachers for survey validation. In addition, because of the problems of identifying the factors, the relationships among the knowledge factors according to the TPCK framework has not been fully tested with structural equation modelling for all the seven factors among preservice teachers. Therefore, this study attempts to address these two gaps.

To attain the research aim, the following research hypotheses were formulated:

$\mathrm{H}_{1.1}$ : CK contributes positively and significantly towards PCK

$\mathrm{H}_{1.2}$ : CK contributes positively and significantly towards TCK

$\mathrm{H}_{1.3}$ : CK contributes positively and significantly towards TPCK

$\mathrm{H}_{1.4}$ : PCK contributes positively and significantly towards TPCK

$\mathrm{H}_{2.1}$ : PK contributes positively and significantly towards PCK

$\mathrm{H}_{2.2}$ : $\mathrm{PK}$ contributes positively and significantly towards TPK

$\mathrm{H}_{2.3}$ : $\mathrm{PK}$ contributes positively and significantly towards TPCK

$\mathrm{H}_{2.4}$ : TCK contributes positively and significantly towards TPCK

$\mathrm{H}_{3.1}$ : TK contributes positively and significantly towards TCK

$\mathrm{H}_{3.2}$ : TK contributes positively and significantly towards TPK

$\mathrm{H}_{3.3}$ : TK contributes positively and significantly towards TPCK

$\mathrm{H}_{3.4}$ : TPK contributes positively and significantly towards TPCK

\section{Participants}

The participants $(\mathrm{N}=550)$ of this research were preservice teachers from four different teacher education institutes in China, Hong Kong, Singapore and Taiwan. These cities/countries were selected because they are mainly from the Chinese origin and may have similar cultural backgrounds and yet are involved in different teacher education programmes. All the four institutes are highly reputable institutes within their respective locality. The mean age of these teachers was 23.5, $\mathrm{SD}=4.7$. The China $(\mathrm{N}=193)$, Hong Kong $(\mathrm{N}=52)$, and Taiwan $(\mathrm{N}=95)$ participants were second or third year undergraduate students. The Singaporean participants $(\mathrm{N}=210)$ had completed their basic degree and were attending a postgraduate diploma course to certify them as teachers. Also, the Singaporean participants composed of multi-races (Chinese, 70\%; Malay, 23\%, Indian, 7\%). Three hundred and seventy-nine of the preservice teachers were female. The ratio of gender distribution was more or less the same for the 3 localities and this is rather typical for preservice teacher education.

\section{Survey Instrument}

The instrument was adapted from Chai et al.'s (2011b) study with several modifications. First, the reference to CK was simplified to just one subject. The preservice teachers from China and Taiwan are trained for one subject specialization. Although the Singaporean and Hong Kong teachers are trained for two teaching subjects, they are usually stronger in their first subject area. Second, factors with only three items were expanded to have at least 4 items per construct so as to increase the validity of each construct. Third, the items of the TPCK factor in Chai et al.'s (2011b) survey were originally adopted from Schmidt 
et al.'s (2009) survey, which were crafted from the integration perspective. They were replaced with items that are focused towards integrating ICT for meaningful learning as proposed by Howland et al. (2012). It is necessary to revise these items to reflect the current practices which emphasize the use of ICT for content learning in authentic, intentional, collaborative and active learning environment. The re-crafted questionnaire containing 36 items was subjected to expert review by two education professors who have published articles on TPCK. The questionnaire was translated into Chinese by the first author, who was a Chinese major in university, and the rest of the authors who were all native Chinese language users, reviewed the translation. The reason for translating the research instrument is that preservice teachers in China, Taiwan and Hong Kong receive their education mainly in Chinese. The bilingual research instrument was posted online for easy access and collection at various locations.

\section{Data Collection and Analysis}

The participants were invited to participate on voluntary basis through their educational technology instructors. After the data had been collected, a preliminary data cleaning was performed to check for missing data or unusual responses (for example, uniform respond for all items). The final set of data from 550 participants was used for further analysis. The skewness (range -.04 to -.99) and kurtosis (range -0.03 to 1.68 ) of all items were first obtained and the results showed that all items can be considered univariate normal as they are within the range recommended by Kline (2005). The data was then factor analysed through confirmatory factor analysis (CFA) with AMOS 20. Items with factor loadings less than 0.5 or were cross-loaded to other factors, and those that exhibited high multi-collinear characteristics were removed. This resulted in the removal of six items (PCK1, PCK2, PCK7, TPCK2, TPK2, PK5). Alpha reliability coefficients and means of each factor were then computed for the factors and a structural equation model was build based on the hypotheses stated.

\section{Findings and Discussion}

Firstly, the CFA performed indicated that the survey yielded seven factors as postulated by the TPCK framework. The fit indices for the survey were $\chi^{2}=1134.5$, degree of freedom $=411, \mathrm{p}<.001, \chi^{2} / \mathrm{df}=2.51$, $\mathrm{TLI}=0.95, \mathrm{CFI}=.96$, RMSEA $=0.05$. According to the guidelines provided by Hair, Black, Babin, and Anderson (2010) for the assessment of model fit, these indices indicate that the 7 factors structure of the survey can be accepted. Table 1 below documents the items and the factor loadings. All factors have reliability coefficients greater than 0.8 . The CFA indicates that the survey instrument is valid and reliable for measuring all seven knowledge factors of the preservice teachers' TPCK. The respective coefficients are CK (0.88), PCK (0.92), PK (0.90), TPCK (0.92), TCK (0.90), TPK (0.91), and TK (0.92).

Table 1

TPCK items and factor loadings

\begin{tabular}{llc}
\hline Factor & \multicolumn{1}{c}{ Items } & $\begin{array}{l}\text { Factor } \\
\text { loadings }\end{array}$ \\
\hline Content Knowledge (CK), $\alpha=0.88$ & \\
\hline CK1 & $\begin{array}{l}\text { 我對於我所教的科目擁有足夠的知識。 } \\
\text { I have sufficient knowledge about my teaching subject. } \\
\text { 我能夠像專家一樣針對所教科目內容進行思考。 }\end{array}$ & .84 \\
CK2 & $\begin{array}{l}\text { I can think about the content of my teaching subject like a } \\
\text { subject matter expert. } \\
\text { 我能夠靠我自己更深入的去理解所教的科目內容。 }\end{array}$ & .77 \\
CK3 & $\begin{array}{l}\text { I am able to gain deeper understanding about the content of my } \\
\text { teaching subject on my own. } \\
\text { 我對於所教科目內容的瞭解程度有充足的信心。 }\end{array}$ & .77 \\
\hline
\end{tabular}




\begin{tabular}{|c|c|c|}
\hline Factor & Items & $\begin{array}{l}\text { Factor } \\
\text { loadings }\end{array}$ \\
\hline \multicolumn{3}{|c|}{ Pedagogical Content Knowledge (PCK), $\alpha=0.92$} \\
\hline PCK3 & $\begin{array}{l}\text { 即使不使用科技，我也能夠幫助學生利用各種方法了解我 } \\
\text { 所教的科目知識。 } \\
\text { Without using technology, I can help my students to understand } \\
\text { the content knowledge of my teaching subject through various } \\
\text { ways. }\end{array}$ & .82 \\
\hline PCK4 & $\begin{array}{l}\text { 即使不使用科技，我也能夠處理學生在我所教的科目中常 } \\
\text { 出現的學習困難。 } \\
\text { Without using technology, I can address the common learning } \\
\text { difficulties my students have for my teaching subject. }\end{array}$ & .84 \\
\hline PCK5 & $\begin{array}{l}\text { 即使不使用科技，我也能夠促進學生在所學習的科目內容 } \\
\text { 中進行有意義的討論。 } \\
\text { Without using technology, I can facilitate meaningful discussion } \\
\text { about the content students are learning in my teaching subject. }\end{array}$ & .88 \\
\hline PCK6 & $\begin{array}{l}\text { 即使不使用科技，我也能夠促使學生解決與我所教科目相 } \\
\text { 關的真實情境問題。 } \\
\text { Without using technology, I can engage students in solving real } \\
\text { world problem related to my teaching subject. }\end{array}$ & .82 \\
\hline PCK8 & $\begin{array}{l}\text { 即使不使用科技，我也能夠協助學生自行管理學習我所教 } \\
\text { 的科目內容。 } \\
\text { Without using technology, I can support students to manage } \\
\text { their learning of content for my teaching subject. }\end{array}$ & .81 \\
\hline \multicolumn{3}{|c|}{ Pedagogical Knowledge (PK), $\alpha=0.90$} \\
\hline PK1 & $\begin{array}{l}\text { 我能夠設計具有挑戰性的任務來延伸學生的思考。 } \\
\text { I am able to stretch my students' thinking by creating } \\
\text { challenging tasks for them. }\end{array}$ & .75 \\
\hline PK2 & $\begin{array}{l}\text { 我能夠指導學生採用合適的學習策略。 } \\
\text { I am able to guide my students to adopt appropriate learning } \\
\text { strategies. }\end{array}$ & .85 \\
\hline PK3 & $\begin{array}{l}\text { 我能夠幫助學生們去監控他們自己的學習。 } \\
\text { I am able to help my students to monitor their own learning. } \\
\text { 我能夠幫助學生反思他們的學習策略。 }\end{array}$ & .85 \\
\hline PK4 & $\begin{array}{l}\text { I am able to help my students to reflect on their learning } \\
\text { strategies. } \\
\text { 我能夠指導學生在團體活動中有效去討論課題。 }\end{array}$ & .84 \\
\hline PK6 & $\begin{array}{l}\text { I am able to guide my students to discuss effectively during } \\
\text { group work. }\end{array}$ & .75 \\
\hline
\end{tabular}




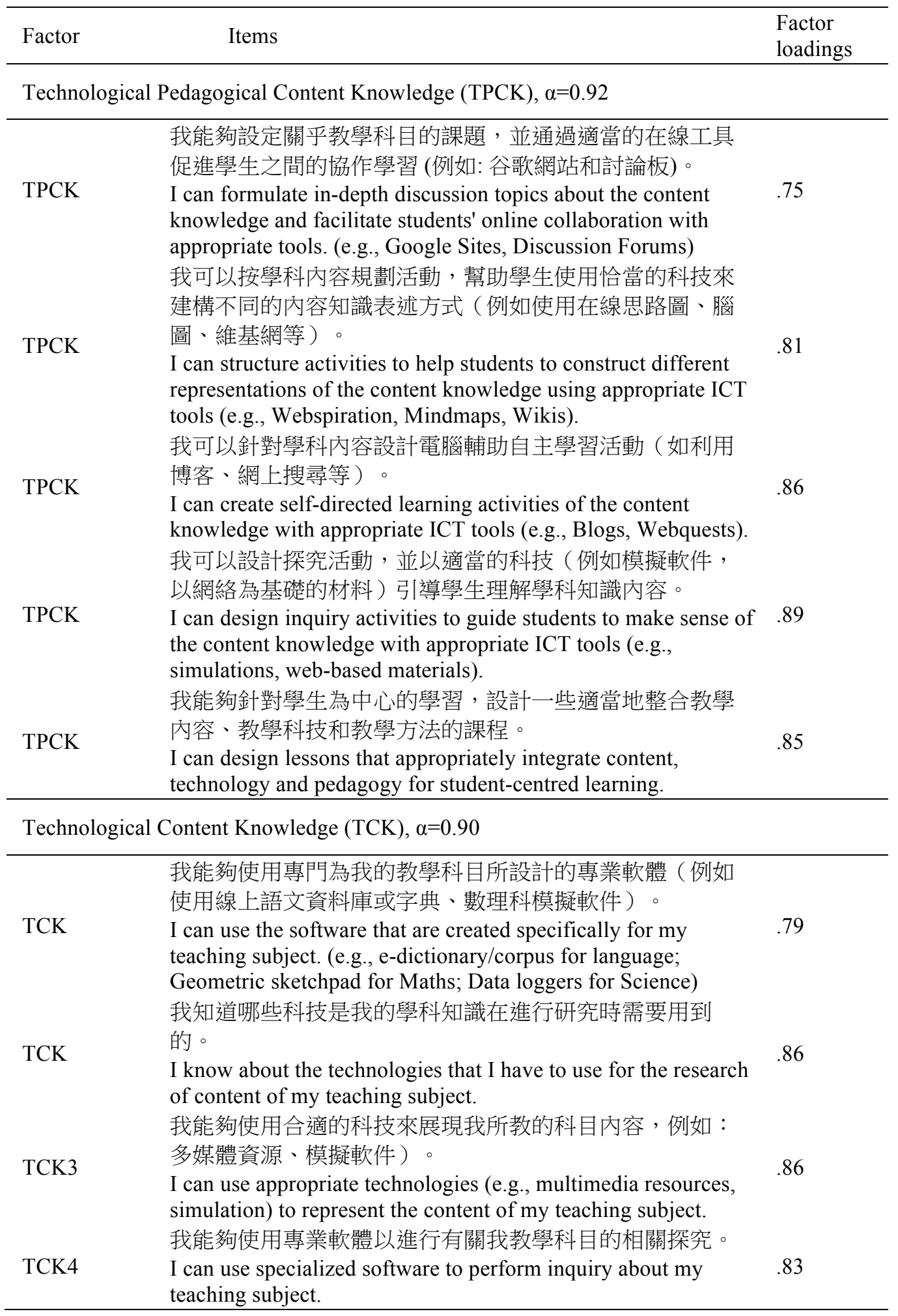




\begin{tabular}{|c|c|c|}
\hline Factor & Items & $\begin{array}{l}\text { Factor } \\
\text { loadings }\end{array}$ \\
\hline \multicolumn{3}{|c|}{ Technological Pedagogical Knowledge (TPK), $\alpha=0.91$} \\
\hline TPK1 & $\begin{array}{l}\text { 我能夠使用科技向學生介紹真實世界的現況。 } \\
\text { I am able to use technology to introduce my students to real } \\
\text { world scenarios. }\end{array}$ & .77 \\
\hline TPK3 & $\begin{array}{l}\text { 我能夠促使學生使用科技來規劃與管理他們自己的學習活 } \\
\text { 動。 } \\
\text { I am able to facilitate my students to use technology to plan and } \\
\text { monitor their own learning. }\end{array}$ & .87 \\
\hline TPK4 & $\begin{array}{l}\text { 我能夠幫助學生使用科技來建構不同的知識表述方式。 } \\
\text { I am able to facilitate my students to use technology to construct } \\
\text { different forms of knowledge representation. }\end{array}$ & .89 \\
\hline TPK5 & $\begin{array}{l}\text { 我能夠促使學生利用科技與同學們一起完成一些作業。 } \\
\text { I am able to facilitate my students to collaborate with each other } \\
\text { using technology. }\end{array}$ & .85 \\
\hline \multicolumn{3}{|c|}{ Technological Knowledge (TK), $\alpha=0.92$} \\
\hline TK1 & $\begin{array}{l}\text { 我具有有效地使用電腦科技的能力。 } \\
\text { I have the technical skills to use computers effectively. }\end{array}$ & .83 \\
\hline TK2 & $\begin{array}{l}\text { 我能夠輕鬆地學習科技。 } \\
\text { I can learn technology easily. }\end{array}$ & .89 \\
\hline TK3 & $\begin{array}{l}\text { 當使用科技時，我知道如何解決我自己所面臨的科技問 } \\
\text { 題。 } \\
\text { I know how to solve my own technical problems when using } \\
\text { technology. }\end{array}$ & .87 \\
\hline TK4 & $\begin{array}{l}\text { 我能跟上重要的新科技發展。 } \\
\text { I keep up with important new technologies. }\end{array}$ & .84 \\
\hline
\end{tabular}

As reported in the literature review, validated surveys for the assessment of preservice teachers TPCK are still lacking (Graham, 2011; Koh et al., 2010; Voogt et al., in press). Through confirmatory factor analysis, we have successfully identified the seven factors among Asian preservice teachers from China, Hong Kong, Singapore and Taiwan. The seven factors represent seven different types of knowledge that can contribute to meaningful use of ICT, thereby providing more refined understanding about what knowledge factors need attention. We believe the survey can serve as a needs assessment tool for teacher educators to identify preservice teachers' learning needs. It can also serve as a tool for the evaluation of courses related to ICT integration or educational technology (Chai et al., 2011a). Voogt et al. (in press) support that such self-assessment tool is useful in providing for the prediction of teachers' actual behaviours. We would suggest that the current survey be further contextualized to the ICT courses provided by the teacher education institutes when it is used as a within institute program evaluation tool to provide more useful and specific information.

In addition, given that the instrument is validated among Asian teachers, albeit limited to Chinese in general, it provides a basis for teacher education institutes to compare the effectiveness of their ICT education for preservice teachers. For many teacher education institutes that provide ICT education, it is difficult to adopt quasi-experimental approaches to test the effectiveness of different instructional approaches. This is because when different instructional approaches for mandatory ICT courses (as is the case for China and Singapore sample) are adopted, it would result in an unstandardized approach and perhaps uneven performances among the preservice teachers. This may cause preservice teachers to feel that they have been unfairly treated. TPCK surveys circumvent these problems to facilitate cross-national and cross-institutional comparisons. We have found interesting and significant differences among the preservice teachers we have surveyed but the results are not reported here as we are still attempting to rule out many extraneous variables because of the diverse cultural and educational differences among our 
participants. Nonetheless, future studies comparing perhaps just two different localities, e.g., Hong Kong and Singapore which share many similarities in their educational system, are likely to be meaningful studies.

Figure 2 below shows the structural equation model we obtained. The fit indices for the model were chisquare $=1143.3$, degree of freedom $=414, p<.001, \chi^{2} / \mathrm{df}=2.72$, TLI $=0.94$, CFI $=.95$, RMSEA $=0.057$. According to Hair et al. (2010), the model can be accepted as demonstrating good fit.

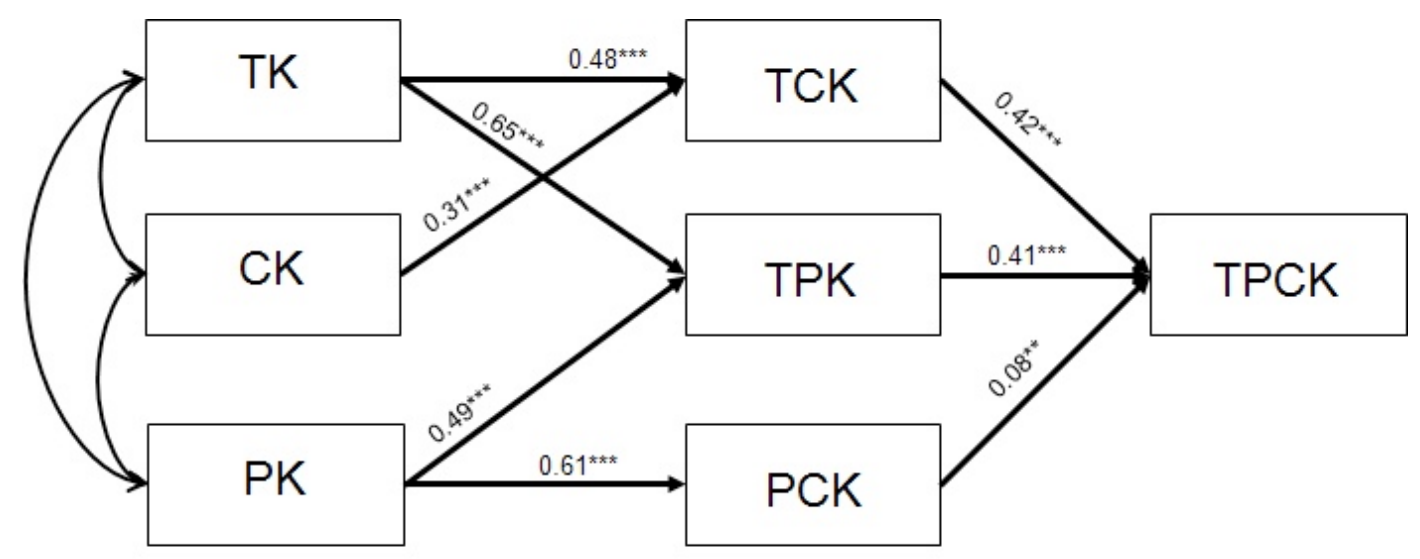

Figure 2. Results of the structural equation model.

Table 2:

The hypotheses and path coefficients for the SEM of TPCK knowledge factors

\begin{tabular}{lccccc}
\hline Hypotheses & $\begin{array}{c}\text { Path } \\
\text { Coefficients }\end{array}$ & $\begin{array}{c}\text { Standard } \\
\text { Error }\end{array}$ & $\begin{array}{c}\text { Critical } \\
\text { Ratio }\end{array}$ & $\begin{array}{c}\text { p } \\
\text { values }\end{array}$ & Supported? \\
\hline $\begin{array}{l}\text { CK contributes positively and } \\
\text { significantly toward PCK }\end{array}$ & 0.09 & 0.05 & 1.68 & 0.09 & No \\
$\begin{array}{l}\text { CK contributes positively and } \\
\text { significantly toward TCK }\end{array}$ & 0.31 & 0.05 & 6.25 & $* * *$ & Yes \\
$\begin{array}{l}\text { CK contributes positively and } \\
\text { significantly toward TPCK }\end{array}$ & 0.00 & 0.04 & 0.02 & 0.98 & No \\
$\begin{array}{l}\text { PCK contributes positively and } \\
\text { significantly toward TPCK }\end{array}$ & 0.08 & 0.03 & 2.48 & 0.01 & Yes \\
$\begin{array}{l}\text { PK contributes positively and } \\
\text { significantly toward PCK }\end{array}$ & 0.61 & 0.08 & 7.86 & $* * *$ & Yes \\
$\begin{array}{l}\text { PK contributes positively and } \\
\text { significantly toward TPK }\end{array}$ & 0.49 & 0.05 & 9.31 & $* * *$ & Yes \\
$\begin{array}{l}\text { PK contributes positively and } \\
\text { significantly toward TPCK }\end{array}$ & -0.01 & 0.05 & -0.08 & 0.94 & No \\
$\begin{array}{l}\text { TCK contributes positively and } \\
\text { significantly toward TPCK }\end{array}$ & 0.42 & 0.04 & 11.09 & $* * *$ & Yes \\
$\begin{array}{l}\text { TK contributes positively and } \\
\text { significantly toward TCK }\end{array}$ & 0.68 & 0.06 & 12.37 & $* * *$ & Yes \\
$\begin{array}{l}\text { TK contributes positively and } \\
\text { significantly toward TPK } \\
\text { TK contributes positively and } \\
\text { significantly toward TPCK } \\
\text { TPK contributes positively and } \\
\text { significantly toward TPCK }\end{array}$ & 0.48 & 0.04 & 11.53 & $* * *$ & Yes \\
\hline $\begin{array}{l}\text { Note. } * * * p<.001 \\
\text { not }\end{array}$ & -0.07 & 0.04 & -1.53 & 0.13 & No \\
\hline
\end{tabular}


As indicated in Figure 2 and also Table 2, only four hypotheses out of 12 hypotheses were not supported. They are: $\mathrm{H}_{1.1}$ : CK contributes positively and significantly toward $\mathrm{PCK} ; \mathrm{H}_{1.3}$ : CK contributes positively and significantly toward TPCK, $\mathrm{H}_{2.3}$ : PK contributes positively and significantly toward TPCK and $\mathrm{H}_{3.3}$ : TK contributes positively and significantly toward TPCK. They were all pertaining to whether or not the basic knowledge factors (CK, PK, TK) have direct positive influences on TPCK and whether CK contributes to PCK. The results indicate that the effects of the basic knowledge factors were indirect, occurring through the second layer of knowledge factors (TPK, TCK, PCK). In addition, the effect of CK on TPCK for this sample of preservice teachers was mediated through TCK. While direct influences of basic knowledge factors were absent, the results do not imply that the knowledge factors were not related. We investigated the correlations of the 7 factors and found out that all factors were positively and significantly related to each other, with correlation ranges from 0.35 to $0.78(\mathrm{p}<.01)$.

The structural equation model we obtained provides good evidence that depicts clearly how the various factors of knowledge contribute to the key construct of TPCK in predominantly Chinese Asian cities/countries. It provides good support for the TPCK theoretical framework by quantitatively verifying that the knowledge factors are connected in the TPCK framework and that the basic knowledge factors contribute to the derived knowledge factors. The finding is somewhat consistent to Mishra and Koehler's (2006) proposition that the key sources of ICT integration knowledge can be found in the inter-connected sources of knowledge such as TPK, TCK, and TPCK. These preservice teachers do not appear to be able to perceive direct connections between TPCK and the basic knowledge sources of TK, PK and CK. It appears that the intermediary sources of knowledge such as TPK and TCK are perceived as stronger building blocks towards TPCK. These findings stand in contrast to Koh, Chai, and Tsai's (2012) model of Singapore practicing teachers' TPCK perceptions. For these teachers, TK, PK, as well as TPK and TCK are perceived to have positive direct influences on their TPCK. It could be that as teachers' experiences with curriculum and teaching practices grow, it better enables them to make direct connections between basic TPCK knowledge sources and TPCK. For preservice teachers, ICT training needs to first develop the intermediary knowledge sources (e.g., TPK and TCK) from their basic knowledge sources, before using these as building blocks towards TPCK. Therefore, developing preservice teachers' intermediary knowledge sources such as TPK and TCK, appear to be more critical than developing their TK, PK, or CK separately.

Another implication of these findings is the importance for teacher educators to model how they make connections between the various TPCK knowledge sources to preservice teachers. Theoretically, the basic knowledge sources of TK, PK, and CK could have direct influences on TPCK. For example, it is not difficult to imagine a teacher who has strong knowledge of how to use online discussion forum (TPK) to incorporate discussion into the learning of certain controversial subject matter (CK). The implication of the study could be that the preservice teachers need to be taught how the various knowledge factors could be treated as knowledge resources and the various pathways of synthesizing the basic and derived knowledge factors to achieve TPCK. When teacher educators draw upon the various factors of TPCK resources to create ICT lessons for meaningful learning, they should make explicit the decision path and the rationale involved to the preservice teachers. This is especially so for decisions involving the basic knowledge components. This form of TPCK reasoning is an identified area for future research (Voogt et al., in press) and it is perhaps because of the lack of clarity in this area that resulted in the broken links as reflected by the four unsupported hypotheses.

In addition, explicit scaffolds are needed as developing TPCK is akin to knowledge creation processes and therefore cognitively very demanding (Kramarski \& Michalsky, 2010). Explicit scaffolds in lesson design could also facilitate the preservice teachers in making the connections between the different forms of knowledge. One such example is provided by Chai, Koh, Ho, \& Tsai (2012) where explicit consideration of all factors of TPCK knowledge is integrated into a lesson design guide. Creativity, flexibility and fluency in connecting the knowledge factors as represented by the TPCK framework would require that the preservice teachers have rich repertoire of the knowledge, and they are able to synthesize them for a specific group of learners with specific learning needs. We would argue that much guidance and experiences are needed for the development of this form of adaptive expertise (Darling-Hammond et al., 2005; Mishra et al., 2009). 


\section{Conclusion and Future Direction}

To combat the limitations of conducting the TPCK survey in one country such as Schmidt et al. (2009), Sahin (2011) and Chai et al. (2011b), which could lead to culturally biased results, this study attempts to validate a TPCK survey that allows teachers' to self-rate their competencies for the seven factors in four Asian areas. We hypothesized that the basic knowledge factors could have direct influence towards the TPCK construct. Contrary to previous studies (Cox \& Graham, 2009; Chai, et al, 2011a, Krauskopf, Zahn, \& Hesse, 2012), this study shows that all seven factors of TPCK were identified. However, direct effects from the basic knowledge factors to TPCK previously reported by Chai et al's (2011a) study, which were unable to identify TCK and PCK as distinct factors, have disappeared. The study therefore attests to the importance of identifying all seven factors in order to make accurate depiction of the relationship between the preservice teachers TPCK factors.

The successful validation of the instrument we created can also be the basis for the design of other more contextualized surveys. This survey is created for general educational technology courses. The items for the various factors can be further contextualized. For example, interested researcher can combine and adapt this survey and Graham et al.'s (2009) survey to form a new survey specifically for science. Graham et al.'s survey was created with only 4 factors (TK, TCK, TPK, and TPCK) and specifically for science content. Further contextualization can also be for the technological factors such as focusing specifically for web 2.0 or online technology only (Archambault \& Barnett, 2010); or it can be for specific pedagogical approach (inquiry-based, problem-based or project-based learning etc.) and for specific content or topic within a subject. These more contextualized surveys could provide more refined and useful understanding for researchers. We forecast that the more contextualized survey will be able to achieve better construct validity since the knowledge involved are more well defined and therefore the problems of unclear boundary would be better addressed (see Cox \& Graham, 2009; Voogt et al., in press). More studies will be needed to discover the possible models given different teacher professional activities pertaining to ICT integration.

Finally, from the perspective of policy making, this study implies a need for teacher education institutes to re-examine the current curriculum guidelines developed for teacher-education program. In addition to helping preservice teachers acquire core knowledge and skills derived from basic knowledge factors, it is equally important that teacher preparation curricula should be reshaped in order to guide preservice teachers to develop and perhaps even create the knowledge in the overlapping areas. Mishra et al. (2009) argue that the new focus of educational technology should be about empowering preservice teachers to experiment and create technology-enhanced learning for specific students and subject matter. Given that, we would argue that the assessment of preservice teachers would necessary include preservice teachers' explicit articulation of their decision making processes with regards to the factors of knowledge they used. In short, there is a need to reconsider what has to be taught and/or created (i.e., the 7 knowledge factors); how it should be taught (modelling, scaffolding and designing) and how preservice teachers' competencies should be assessed (pedagogical reasoning and decision making).

\section{Acknowledgements}

The authors would like to thank all the participants and also their colleagues for collecting the data. Furthermore, Dr. Hong would also like to acknowledge the support for conducting this study, in part, from grant NSC\#99-2511-S-004-002-MY3.

\section{References}

AACTE (Ed.). (2008). Handbook of technological pedagogical content knowledge (TPCK) for educators. New York: Routledge.

Angeli, C., \& Valanides, N. (2005). Preservice elementary teachers as information and communication technology designers: an instructional systems design model based on an expanded view of pedagogical content knowledge. Journal of Computer Assisted Learning, 21(4), 292-302. 
Angeli, C., \& Valanides, N. (2009). Epistemological and methodological issues for the conceptualization, development, and assessment of ICT-TPCK: Advances in Technological Pedagogical Content Knowledge (TPCK). Computers \& Education, 52(1), 154-168.

Archambault, L. M., \& Barnett, J. H. (2010). Revisiting technological pedagogical content knowledge: Exploring the TPCK framework. Computers \& Education, 55(4), 1656-1662.

Chai, C. S., Koh, J. H. L., \& Tsai, C.-C. (2011b). Exploring the factor structure of the constructs of technological, pedagogical, content knowledge (TPACK). The Asia-Pacific Education Researcher, 20(3), 607-615.

Chai, C. S., Koh, J. H. L., Ho, J., \& Tsai, C.-C. (2012). Examining preservice teachers' perceived knowledge of TPACK and cyberwellness through structural equation modeling. Australasian Journal of Educational Technology, 28(6), 1000-1019.

Chai, C. S., Koh, J. H. L., Tsai, C.-C. \& Tan, L. (2011a). Modeling primary school preservice teachers' Technological Pedagogical Content Knowledge (TPACK) for meaningful learning with information and communication technology (ICT). Computers \& Education, 57, 1184-1193.

Collins, A., \& Halverson, R. (2010). The second educational revolution: rethinking education in the age of technology. Journal of Computer Assisted Learning, 26(1), 18-27.

Cox, S., \& Graham, C. R. (2009). Diagramming TPCK in Practice: Using and elaborated model of the TPCK framework to analyze and depict teacher knowledge. TechTrends, 53(5), 60-69.

Darling-Hammond, L., \& Bransford, J., LePage, P., Hammerness, K., \& Duffy, H. (Eds.) (2005). Preparing teachers for a changing world: What teachers should learn and be able to do. San Francisco: Jossey-Bass.

Ertmer, P. A. (2005). Teacher pedagogical beliefs: The final frontier in our quest for technology integration. Educational Technology Research and Development, 53(4), 25-39

Graham, C. R. (2011). Theoretical considerations for understanding technological pedagogical content knowledge (TPCK). Computers \& Education, 57, 1953-1960.

Graham, R. C., Burgoyne, N., Cantrell, P., Smith, L., St. Clair, L., \& Harris, R. (2009). Measuring the TPCK confidence of inservice science teachers. TechTrends, 53(5), 70-79.

Hair, J. F., Black, W. C., Babin, B. J., \& Anderson, R. E. (2010). Multivariate Data Analysis: A global perspective (7th ed.). Upper Saddle River, NJ: Pearson.

Harris, J., Mishra, P., \& Koehler, M. (2009). Teachers' technological pedagogical content knowledge and learning activity types: Curriculum-based technology integration reframed. Journal of Research on Technologyin Education, 41(4), 393-416.

Hong, H., \& Sullivan, F. R. (2009). Towards idea-centered, principle-based design approach to support learning as knowledge creation. Educational Technology, Research \& Development. 57(5), 613-627.

Howland, J., Jonassen, D., \& Marra, R. (2012). Meaningful learning with technology (4th ed.). Upper Saddle River, NJ: Pearson.

Kline, R. B. (2005). Principles and practice of structural equation modeling (2nd ed.). New York: The Guilford Press.

Koehler, M. J., \& Mishra, P. (2005). What happens when teachers design educational technology? The development of technological pedagogical content knowledge. Journal of Educational Computing Research, 32(2), 131-152.

Koehler, M. J., Mishra, P., \& Yahya, K. (2007). Tracing the development of teacher knowledge in a design seminar: Integrating content, pedagogy and technology. Computers \& Education, 49(3), 740762 .

Koehler, M., \& Mishra, P. (2009). What is Technological Pedagogical Content Knowledge (TPCK)? Contemporary Issues in Technology and Teacher Education, 9(1), 60-70. 
Koh, J. H. L., Chai, C. S., \& Tsai, C. C. (2012). Examining practicing teachers' perceptions of technological pedagogical content knowledge (TPACK) pathways: A structural equation modeling approach. Instructional Science. doi: 10.1007/s11251-012-9249-y

Koh, J.H.L., Chai, C.S., \& Tsai, C.C. (2010). Examining the technological pedagogical content knowledge of Singapore preservice teachers with a large-scale survey. Journal of Computer Assisted Learning, 26, 563-573.

Kramarski, B., \& Michalsky, T. (2010). Preparing preservice teachers for self-regulated learning in the context of technological pedagogical content knowledge. Learning and Instruction, 20(5), 434-447.

Krauskopf, K., Zahn, C., \& Hesse, F. W. (2012). Leveraging the affordances of Youtube: The role of pedagogical knowledge and mental models of technology functions for lesson planning with technology. Computers \& Education, 58, 1194-1206.

Lee, M. H., \& Tsai, C. C. (2010). Exploring teachers' perceived self efficacy and technological pedagogical content knowledge with respect to educational use of the World Wide Web. Instructional Science, 38, 1-21.

Manfra, M., \& Hammond, T. C. (2008). Teachers' instructional choices with student-created digital documentaries: Case studies. Journal of Research on Technology in Education, 41(2), 223-245.

Mishra, P., \& Koehler, M. J. (2006). Technological pedagogical content knowledge: A framework for teacher knowledge. Teachers College Record, 108(6), 1017-1054.

Mishra, P., Koehler, M. J. \& Kereluik, K. (2009). The song remains the same: Looking back to the future of educational technology. Techtrends, 53(5), 48-53.

Niess, M. L. (2005). Preparing teachers to teach science and mathematics with technology: Developing a technology pedagogical content knowledge. Teaching and Teacher Education. 21(5), 509-523.

Polly, D., Mims, C., Shepherd, C. E., \& Inan, F. (2010). Evidence of impact: Transforming teacher education with preparing tomorrow's teachers to teach with technology (PT3) grants. Teaching and Teacher Education, 26, 863-870.

Sahin, I. (2011). Development of survey of technological pedagogical and content knowledge (TPCK). Turkish Online Journal of Educational Technology, 10(1), 97-105.

Schmidt, D. A., Baran, E., Thompson, A. D., Mishra, P., Koehler, M. J., \& Shin, T. S. (2009). Technological Pedagogical Content Knowledge (TPCK): The development and validation of an assessment instrument for preservice teachers. Journal of Research on Technology in Education, 42(2), 27.

Shulman, L. S. (1986). Those who understand: Knowledge growth in teaching. Educational Researcher, 15(2), 4-14.

Tee, M., \& Lee, S. (2011). From socialisation to internalisation: cultivating technological pedagogical content knowledge through problem-based learning. Australasian Journal of Educational Technology, 27(1), 89-104.

Voogt, J., Fisse, P., Pareja Roblin, N., Tondeur, J., \& van Braak, J. (In press). Technological pedagogical content knowledge - a review of the literature. Journal of Computer Assisted Learning. doi: 10.1111/j.1365-2729.2012.00487.x

Corresponding author: Eugenia M W Ng, eugenia@ied.edu.hk

Australasian Journal of Educational Technology (C) 2013.

Please cite as: Chai, C. S., Ng, E. M. W., Li, W., Hong, H.-Y., \& Koh, J. H. L. (2013). Validating and modelling technological pedagogical content knowledge framework among Asian preservice teachers. Australasian Journal of Educational Technology. 29(1), 41-53. 